Józef Wacław Boguniowski SDS

\title{
Przedtrydenckie lekcjonarze mszalne
}

Złoty wiek rzymskiej liturgii (IV i V) wywarł wielki wpływ na specyfikę czytań. Już w IV wieku ukazują się razem zestawy czytań lekcji i Ewangelii ${ }^{1}$, tzw. capitularia plenaria. Ze znanych najstarszych, jednak nie zachowanych, uważa się Comes św. Hieronima († 420). Poprzedza go Epistula ad Constantium, w której wymienione są czytania ze Starego Testamentu, listy kanoniczne i Ewangelie. Po roku 400 ukazują się pełne teksty lekcji i Ewangelii w jednej księdze, którą nazywa się lectionarium plenarium lekcjonarzem. Ojczyzną tej księgi liturgicznej jest Galia i Górna Italia, a miejscem redakcji - zdaniem K. Gambera - miała być Rawenna ${ }^{2}$. Do naszych czasów nie zachowały się z nich kompletne egzemplarze. Nie mniej na uwagę zasługują ich fragmenty pochodzące z Italii i Galii.

\section{Lekcjonarze mszalne w języku łacińskim}

\section{Italia}

Na terenie Górnej Italii po wydaniu przez cesarza Justyniana I (527-565) w roku 529 tzw. Codex Justinianus, zaistniały sprzyjające warunki dla kompilacji tekstów liturgicznych. Już przed pontyfikatem Grzegorza Wielkiego $(†$ 604) powstała odrębna księga z perykopami epistoł i Ewangelii, która służyła subdiakonowi i diakonowi w celebracji uroczystej Mszy świętej. Za jej redaktora uważa się Maksymiliana z Rawenny (546-553).

\section{MONACHIJSKI FRAGMENT LEKCJONARZA}

W Bawarskiej Bibliotece Miejskiej w Monachium znajduje się fragment księgi czytań pod sygn. Clm 29155c. z końca VI wieku. Jest on napisany pismem uncjalnym ok. 25 wierszy w dwóch kolumnach. Zachował się tekst Ewangelii z Wielkiego Poniedziałku (J 12, 1-36) i lekcja z Wielkiego Wtorku (Jer 11, 18-20). Fragment ten wskazuje na wyłączny rzymski obrzęd.

${ }^{1}$ Zdaniem H. EngBerding, Lektionar, [w:] LThK 1, VI, 478: „Im römischen Ritus enthielt das Lektionar in der Regel die nicht evangelischen Lesungen der Messe. Heute ist hier eine Buchform gebräuchlich, die Epistel und Evangelium in sich vereinigt". 
FRAGMENTY KSIĘGI PERYKOP EPISTOŁ I EWANGELII Z VIII WIEKU

Alban Dold OSB, słynny „ojciec fragmentów liturgicznych”, znalazł m.in. fragmenty księgi czytań mszalnych w oprawie inkunabułów nr 6769 i nr H 5385 przechowywanych we Württenbergische Landesbibliothek w Stuttgarcie. Na kartach pergaminowych formatu 15,6 $\times 22,2 \mathrm{~cm}$ umieszczono w jednej kolumnie tekst liczący po 21 wierszy. Niektóre formularze perykop są oznaczone liczbą porządkową. Tytuły formularzy wypisano pismem uncjalnym, a tytuły ksiąg Pisma Świętego, z których zaczerpnięto perykopy atramentem zielonym, pozostałe teksty napisano minuskułą wczesnokarolińską. Majuskułę mają inicjały nowych fragmentów. Dla zaznaczenia początku nowego formularza zastosowano kolorowe inicjały. Znalazca na podstawie charakterystycznej pisowni i układu treści stwierdzit, że księga liturgiczna została zredagowana w okolicy Jeziora Bodeńskiego, może w Reichenau lub w St. Gallen ${ }^{2}$, przed pontyfikatem papieża Grzegorza II (715731), który wprowadził msze czwartkowe. Fragmenty rękopisu zawierają perykopy ze Starego Testamentu (z ksiąg prorockich) i z Nowego Testamentu (z Listów apostolskich i z Ewangelii) przeznaczone na poniedziałek, wtorek, środę i piątek po pierwszej niedzieli i na szóstą niedzielę wielkiego postu, na piątek i sobotę Suchych Dni w okresie letnim oraz na czwartą niedzielę po Zesłaniu Ducha Świętego. Księga czytań mszalnych była używana dość wcześnie w kościołach uboższych, ponieważ jedynie bogatsze wspólnoty liturgiczne mogły nabyć cały tekst Pisma Świętego, z którego czytano określone perykopy mszalne.

Studium porównawcze znalezionych fragmentów z listą perykop z Murbach wykazało, że ostatni kodeks jest bogatszy od tekstu pierwszego o jedenaście perykop. Natomiast tekst ze Stuttgartu jest archetypem listy z Murbach i reprezentuje tradycję rzymską przekazaną przez kraje galijskie 4 .

WATYKAŃSKI FRAGMENT LEKCJONARZA

Fragment księgi czytań znajdujący się w Watykanie jako Cod. Vat. lat 5775 pochodzi z ok. 850 r. Podwójna karta zawiera czytania od piątej do szóstej niedzieli Objawienia Pańskiego z potrójnym systemem lekcyjnym.

\section{Galia}

Spośród lekcjonarzy mszalnych w języku łacińskim pochodzenia galijskiego na uwagę zasługują dwa niekompletne kodeksy z Wolfenbüttel i z Luxeuil.

${ }^{2}$ Zob. A. Dold, Ein Vorläufer, 243.

${ }^{3}$ Przed pontyfikatem Grzegorza II czwartek był dniem aliturgicznym.

${ }^{4}$ Zob. A. Dold, Ein Vorläufer, 246-249 


\section{LECTIONARIUM (PALIMPSEST) Z WOLFENBÜTTEL}

Kodeks ten znajduje się w Herzog August Bibliothek w Wolfenbüttel Cod. Weissenburgensis 76. Pochodzi z klasztoru z Weissenburg z początku VI wieku. Charakteryzuje się bogactwem perykop. Na każdy dzień tygodnia ma trzy czytania: jedno ze Starego Testamentu i dwa z Nowego Testamentu, tj. $z$ listów św. Pawła i Ewangelii, dobrane według idei przewodniej określonego dnia liturgicznego. Zbiór perykop rozpoczyna się perykopami na Wigilię Paschalną. Z upływem czasu nieczytelnymi stały się tytuły perykop. Redaktorem tej księgi liturgicznej był prawdopodobnie kapłan, uczony biblista i liturgista Musaeus z Marsylii $(\dagger 461)^{5}$.

\section{LECTIONARIUM LUXOVIENSE}

W Bibliotece Narodowej w Paryżu pod sygn. ms. lat. 9427 znajduje się niekompletna księga liturgiczna z perykopami Epistoł i Ewangelii pochodząca z przełomu VII i VIII wieku' ${ }^{6}$. Odnalazł ją J. Mabillon w klasztorze w Luxeuil. Zagadnienie miejsca jej powstania było przedmiotem studiów liturgistów ${ }^{7}$. Na pochodzenie galijskie tej księgi liturgicznej wskazują czytania na uroczystość św. Genowefy, która była wówczas czczona we Francji, i charakterystyczna cecha merowińska - trzy czytania na każdą Mszę świętą .

Uszkodzony kodeks rozpoczyna się wigilią Bożego Narodzenia, a kończy się na Lectiones cotidianas. Poszczególne formularze perykop mają numerację ciągłą i zawierają trzy czytania (Stary Testament, Listy św. Pawła i Ewangelie) na każdą Mszę świętą. Księga ta reprezentuje zupełnie inny typ lekcjonarza niż wyżej wymieniony z Wolfenbüttel. Za redaktora omawianej księgi przyjmuje się Klaudiusza Mamertusa z Vienny († ok. 474), o którym Sidonius Apollinaris powiedział: Hic sollemnibus annuis paravit, quae quo tempore lecta convenirent ${ }^{9}$. P. Salmon opublikował lekcjonarz z Luxeuil w dwóch tomach ${ }^{10}$.

\section{Polska}

Do Polski lekcjonarz przedostał się w nieznanych nam bliżej okolicznościach, o czym świadczy fragment kodeksu z Biblioteki Katedralnej we Włocławku, składający się z dwóch kart, formatu A4, o brzegach mocno znisz-

${ }^{5}$ GAMBer, Codices, nr 250.

${ }^{6}$ L. Duchesne, Origines du culte chrétien, Paris $1903^{3}, 113$.

${ }^{7}$ Np. EISENHOFER, Liturgik, I, 85, przypuszcza, że rękopis ten został napisany w Paryżu; P. SALMON, Le lectionnaire de Luxeuil. Ses origines et l'Eglise de Langres, RBén 53 (1941), 89-107.

${ }^{8}$ Zob. S. GALl, Lekcyonarz gallikański, [w:] Podręczna Encyklopedia Kościelna, pod red. Z. Chełmickiego, XXIII-XXIV, Warszawa 1911, 260.

${ }^{9}$ Cyt. za Gamber, Codices, nr 037.

${ }^{10}$ Città del Vaticano 1941 i 1953. 
czonych. Odnalazł go Władysław Semkowicz w oprawie jednego z kodeksów z XV wieku w Bibliotece Kapitulnej we Włocławku. Na pergaminie widnieje część tekstu perykop wielkiego postu, pisanych w dwóch kolumnach pismem prekarolińskim zachodnim z przełomu VIII i IX wieku. Odkrywca sądzi, że ów fragment był niegdyś własnością katedry kruszwickiej i jako zniszczony, przestarzały i nieczytelny został użyty przy oprawie rękopisu z XV wieku. Fragment ten znajduje się obecnie w zbiorach Zakładu Nauk Pomocniczych Historii Uniwersytetu Jagiellońskiego w Krakowie ${ }^{11}$.

\section{Lekcjonarze mszalne w językach narodowych}

Jak długo język łaciński w liturgii rzymskiej był zrozumiały dla uczestniczących w niej i dopóki języki nowożytne były w stadium ich powstawania, nie było potrzeby ani możliwości tłumaczenia perykop mszalnych na język ojczysty. Sytuacja zmieniła się z chwilą zaistnienia ewangelizacji narodów anglosaskich i słowiańskich. Misjonarze i duszpasterze w nauczaniu prawd wiary posługiwali się językiem zrozumiałym dla ludu ${ }^{12}$. Nowo nawróceni, nie znający języka łacińskiego, domagali się wprowadzenia także języka ojczystego do liturgii. Ponieważ język łaciński, a uprzednio język grecki, uważany był za język sakralny, stąd zrodził się problem wprowadzenia języka narodowego do liturgii. Gorliwi duszpasterze posługiwali się w sprawowaniu Mszy świętych i w szafarstwie sakramentów świętych językiem narodowym, czego dowodem są lekcjonarze i rytuały pochodzące sprzed soboru trydenckiego. Gdy zapytamy o czas wprowadzenia języka ojczystego po raz pierwszy do Liturgii Słowa we Mszy świętej, trudno to stwierdzić. W każdym narodzie, w zależności od rożnych czynników twórczych, był on inny. Najprawdopodobniej lekcjonarze z perykopami biblijnymi w językach narodowych nie powstały od razu, lecz poprzedzały je tłumaczenia częściowe, to znaczy najpierw perykopy ewangeliczne na uroczystości i niedziele ${ }^{13}$, później perykopy epistoł dla tych samych celebracji. Po nich niestety nie zachowała się żadna dokumentacja.

$\mathrm{Na}$ podstawie dostępnej nam literatury wiemy, że na język angielski przetłumaczono cały tekst Pisma Świętego w latach 1380-1384, a w roku 1560 Biblia ukazała się drukiem ${ }^{14}$. W języku francuskim po raz pierwszy

${ }^{11}$ Zob. Semkowicz, Paleografia, 297-298; M. SokoŁowski, dz. cyt., 17-18.

12 Zob. P. Sczaniecki, Stużba Boża w dawnej Polsce, t. 1, Poznań 1962, 75; W. Schenk, Z dziejów, t. 1, Lublin 1969, 151.

${ }^{13}$ S. Rospond, Kościót w dziejach języka polskiego, Wrocław 1985, 61: „Ślady ewangeliarza staropolskiego zachowały się w kazaniach polsko-łacińskich z XV w.”.

${ }^{14}$ Zob. P. SKEHAN, J. SCHMID, Englische Bibelübersetzung, [w:] LThk 2, II, 404. 
ukazała się Biblia po roku 1226, to jest za panowania Ludwika Pobożnego, a drukiem w Antwerpii w roku $1530^{15}$. W starogórnoniemieckim języku mamy Ewangelie z ok. 830 roku z St. Gallen oparte na Codex Fuldensis. Ze średniowiecza zachowały się 43 rękopisy Pisma Świętego w języku niemieckim. Czternaście wydań Pisma Świętego w górnoniemieckim języku ukazało się drukiem w latach od 1461 (1466?) do 1522 (pierwszego wydania Biblii przez M. Lutra). Pierwsze tłumaczenia Pisma Świętego w rękopisach i w inkunabułach oparte były na tekście łacińskiej Wulgaty. Od początku tekstowi perykop towarzyszyły glosy homiletyczne ${ }^{16}$. Otfrid v. Weißenburg OSB (ur. ok. 790 roku) w dialekcie południoworeńskofrankońskim napisał ewangelistarz: Liber evangeliorum theodisce conscriptus. Księga ta została zredagowana według systemu perykop z preferencją Ewangelii wg św. Jana ${ }^{17}$. J. A. Jungmann ${ }^{18}$ powołuje się na Gerberta ${ }^{19}$, który wymienia m.in. zbiór epistoł $\mathrm{w}$ języku niemieckim powstały w roku 1210. Zbiór ten prawdopodobnie był przeznaczony dla kultu publicznego. Wiadomości na temat lekcjonarzy w języku włoskim pochodzą z publikacji Giuseppe Landottiego $\mathrm{CM}^{20}$.

Obok Niemiec najwięcej lekcjonarzy w języku narodowym powstało w Italii. Badania w tej materii wykazały, że do naszych czasów z tego rodzaju ksiąg zachowało się 50 rękopisów i 320 starodruków. Inicjatywa tłumaczenia Biblii na język narodowy wyszła we Włoszech od wiernych, którzy pragnęli doskonalej poznać słowo Boże. Zdaniem Alberto Vaccariego w XIII w. w różnych regionach Italii tłumaczono najpierw fragmenty Biblii na język narodowy dla potrzeb liturgii mszalnej i Liturgii Godzin ${ }^{21}$. Za fragmentarycznym tłumaczeniem Pisma Świętego przemawiały względy ekonomiczne i praktyczne. Były one przeznaczone dla ludności średnich klas społecznych. Najstarsze znane rękopisy lekcjonarzy w języku włoskim pochodzą z XIV w. Jedenaście zachowanych rękopisów pełnych lekcjonarzy z XIV i XV w. cechuje prostota graficzna i zdobnicza ${ }^{22}$. Pod tym względem różnią się one od bogatych rówieśniczych kodeksów francuskich i nie-

${ }^{15}$ Zob. E. Beaucamp, J. Schmid, Französische Bibelübersetzung, [w:] LThk 2, II, 407.

${ }^{16}$ Zob. W. KäMPFER, Plenarium, [w:] LThk 2, VIII, 559-560.

${ }^{17}$ Zob. L. SCHEFFCZYK, Otfrid v. Weißenburg, [w:] LThk 2, VII, 1298.

${ }^{18}$ Zob. Jungmann, MS, I, 522, przypis 26.

${ }^{19}$ Gerbert, Vetus Liturgia Alemanica, I, 125nn.

${ }^{20}$ G. LANDOtTI, I lezionari in lingua italiana nei secoli XIII-XIX, EL 88 (1974), 401-446, które jest częścią tezy doktorskiej: Le traduzioni del Missale in lingua italiana prima del movimento liturgico moderno, przedstawionej w Papieskim Instytucie Liturgicznym S. Anselmo w Rzymie.

${ }^{21} \mathrm{Za}$ G. LANDOTTI, art. cyt., 403.

${ }^{22}$ G. LANDOTTI, art. cyt., 404, 430-431. 
mieckich. Po wynalezieniu druku (1450) od roku 1470 do roku $1500 \mathrm{w}$ Italii ukazało się 35 wydań lekcjonarza w języku narodowym ${ }^{23}$. Gdy rękopisy lekcjonarzy prawie wyłącznie pochodziły z Florencji, to centrum produkcji starodruków znajdowało się w Wenecji ${ }^{24}$. W niej ukazało się 16 wydań tej księgi. Z reguły była ona wierną reprodukcją rękopisu będącego w obiegu. W żadnym $\mathrm{z}$ wydań lekcjonarza nie podano nazwiska tłumacza. Jedynie $\mathrm{z}$ kolofonów znane nam są nazwiska wydawców i drukarzy ${ }^{25}$. Pierwsze starodruki pod względem typograficznym wzorowały się na oficjalnych lekcjonarzach łacińskich. Miały ten sam incipit perykop, jednakowy układ tekstu w dwóch kolumnach i ten sam format. $\mathrm{Z}$ wymienionych cech nie można wnioskować, że te lekcjonarze w języku włoskim były używane z reguły przez liturgów we Mszy świętej ${ }^{26}$. We Włoszech w przeciwieństwie do Niemiec, w XVI wieku notuje się znaczny wzrost produkcji tego rodzaju ksiąg. W tym wieku pojawiali się nowi tłumacze tekstu, jak np. Antonio Brucioli $^{27}$, a ich nazwiska umieszczano w dawnej publikacji.

W Wenecji w okresie soboru trydenckiego od roku 1546 do 1591 drukowano lekcjonarze dwujęzyczne: łacińsko-włoskie, których format stopniowo zmniejszano, od formatu mszalnego do podręcznego $(10,00 \times 15,00$ $\mathrm{cm})$. Duża ilość wydań lekcjonarza w języku włoskim nie była przeznaczona wyłącznie dla duchowieństwa lub uczonych, lecz służyła szerokiemu kręgowi wiernych ${ }^{28}$.

Pod wpływem uchwał soboru trydenckiego lekcjonarz w języku włoskim został przekształcony w postylle.

W Polsce, podobnie jak w innych krajach, przekłady niektórych ksiąg Pisma Świętego, zwłaszcza Księgi Psalmów, np. Psałterz Floriański (XIV w.), zaczęły się od drugiej połowy XIII w., a tłumaczenia na język polski całej Biblii dokonano w roku 1455 . Z pierwszym wykazem perykop ewangelicznych na każdą niedzielę w języku polskim spotykamy się w Kalendarzu Michata $z$ Wiślicy z roku $1539^{29}$. Pierwszy znany Kapitularz epistot $i$ Ewangelii w języku polskim wydał J. Seklucjan w edycji Nowego Testamentu w roku 1551. Dziesięć lat później, kapitularz z początkowymi i końcowymi słowami perykop lekcji i Ewangelii w języku polskim został umieszczony na końcu Biblii

${ }^{23} \mathrm{Z}$ tych wydań zachowało się w Italii ok. 33 inkunabułów, a za granicą ok. 20. Za G. LANDOTTI, 409.

${ }^{24}$ Tenże, 411.

${ }^{25}$ Wykaz nazwisk drukarzy podał G. LANDOTTI, art. cyt., 411.

${ }^{26}$ Zob. G. LANDOTTI, art. cyt., 416.

${ }^{27}$ Przetłumaczył całą Biblię na język włoski w roku 1532. Zob. C. CRIVELLI, [w:] ECat, III, 130.

${ }^{28}$ Zob. G. LANDOTTI, art. cyt., 418, 430.

${ }^{29}$ Zob. J. JANów, Nowy ewangeliarz polski z XVI w., Kraków 1949, 5. 
Leopolity. Słusznie więc twierdzi Felicjan Kłoniecki, że praktyka czytania perykop biblijnych w języku polskim we Mszy świętej była już znana w okresie soboru trydenckiego ${ }^{30}$. Świadkami następnej fazy rozwojowej lekcjonarza w Polsce są następujące dokumenty: Pierwszym dokumentem jest rękopis zwany Plenariuszem Krakowskim z roku 1445, w którym obok kazań łacińskich znajdują się perykopy lekcyjne i ewangeliczne w języku polskim ${ }^{31}$. Drugim dokumentem jest Nowy Testament drukowany u Scharffenberga w Krakowie w roku 1556 i 1568, do którego dołączono perykopy lekcyjne ze Starego Testamentu $^{32}$. Najstarszym lekcjonarzem w ścisłym tego słowa znaczeniu w języku polskim jest tak zwana Postylla polska $a^{33}$. Jej jedyny egzemplarz pierwszej edycji, która ukazała się w Krakowie w roku 1557 u Wirzbięty, zachował się w Szwecji. Ostatnie wydanie lekcjonarza ukazało się w Królewcu w roku $1581^{34}$. Na uwagę zasługuje rękopis puławski z roku 1573, chociaż przekracza ramy chronologiczne naszej rozprawy. Przez Jana Janowa został on mylnie nazwanym Ewangeliarzem ${ }^{35}$. Tytuł rękopisu: Ordo epistolarum et evangeliorum, i jego zawartość przemawiają za tym, żeby go zaliczyć do ksiąg liturgicznych kategorii lekcjonarzy. Kodeks ten przechowywany w Muzeum Czartoryskich w Krakowie pod sygn. 2408, został opisany przez Jana Janowa ${ }^{36}$.

\section{Literatura pomocnicza}

Beaucamp E., Schmid J., Französische Bibelübersetzung, [w:] LThk, II, Freiburg 1958², 407.

Dold A., Ein Vorlaufer des Comes von Murbach, EL 65 (1951), 237-252.

DuCHESNE L., Origines du culte chrétien. Etude sur la liturgie latine avant Charlemagne, Paris $1903^{3}$.

EISENHOFER L., Handbuch der katholischen Liturgik, I-II, Freiburg i. Br. 1941-1942².

ENGBERding H., Lektionar, [w:] LThk, VI, Freiburg i. Br. 1934, 478-479.

Gall S., Księgi liturgiczne, [w:] Podręczna encyklopedia kościelna, red. Z. Chełmiński, XXIIIXXIV, Warszawa 1911, 260.

GAMBER K., Codices liturgici latini antiquiores, Fribourg $1968^{2}$.

Gamber K., Das Münchener Fragment eines Lectionarium Plenarium, EL 72 (1958), 268-280. JANów J., Nowy ewangeliarz z XVI w., Kraków 1949.

${ }^{30}$ Zob. F. KŁONIECKI, Perykopy biblijne w świetle orzeczeń Kościoła, [w:] Pismo Święte w duszpasterstwie wspótczesnym, pod red. E. Dąbrowskiego, Lublin 1958, 125; por. J. STĘPIEŃ, Przebieg zjazdu i jego znaczenie, [w:] Pismo Święte w duszpasterstwie wspótczesnym, pod red. E. Dąbrowskiego, Lublin 1958, 281.

${ }^{31}$ Zob. F. KŁONIECKI, art. cyt., 126.

${ }^{32}$ Por. tenże, 125.

${ }^{33}$ Nazewnictwo jest niewłaściwe. Nie ma bowiem w niej śladów kazań. Dotąd nie zbadano, z jakiego pochodzi środowiska: katolickiego czy protestanckiego. Zob. J. JANów, dz. cyt., 6.

${ }^{34}$ Tamże.

${ }^{35}$ J. JANów, Nowy ewangeliarz z XVI w., Kraków 1949.

${ }^{36}$ Tamże. 
Jungmann J. A., Missarum Sollemnia, I-II, Wien ${ }^{5} 1962$.

KÄMPFER W., Plenarium, w: LThk, VIII, Freiburg ${ }^{2} 1963$, 559-560.

KŁONIECKI F., Perykopy biblijne w świetle orzeczeń Kościoła, w: Pismo Święte w duszpasterstwie wspótczesnym, pod red. Eugeniusza Dąbrowskiego, Lublin 1958, 121-140.

LANDOtTi G., I lezionari in lingua italiana nei secoli XIII-XIX, EL 88 (1974), 401-446.

RosPOnd S., Kościót w dziejach języka polskiego, Wrocław 1985.

SCHEFFCZYK L., Otfrid v. Weißenburg, w: LThk ${ }^{2}$, VII, 1298.

Schenk W., Z dziejów liturgii w Polsce, w: Ksiegga tysiąclecia katolicyzmu w Polsce, pr. zb. pod red. M. Rechowicza, I, Lublin 1969, 142-149.

Sczaniecki P., Stużba Boża w dawnej Polsce, I-II, Poznań 1962-1966.

Semkowicz, W., Paleografia tacińska, Kraków 1951.

Skehan P., Schmid J., Englische Bibelübersetzung, w: LThk, II, Freiburg 21958, 404.

SokoŁowski M., Rzeźba z kości stoniowej XI wieku i najstarsze ksiąziki liturgiczne w Polsce, Kraków 1896.

Bielsko-Biała

JÓZEF WACŁAW BOGUNIOWSKI SDS 